\title{
Ethical Issues in Global Supply Chains
}

\author{
Bodo B. Schlegelmilch*, Magdalena Öberseder ${ }^{* *}$
}

\begin{abstract}
Despite all technological advances, global supply chains are always based on the interaction of people. And wherever people interact, a kaleidoscope of ethical issues emerges.

While consumer demands and concerns have undoubtedly led to an increased awareness of unethical conduct in the supply chain, contravening forces, such as the relentless pressures for low cost products and the ease by which consumers are purchasing non-deceptive counterfeits, should also not be ignored.

Many retailers are now embracing ethical issues by emphasising, for example, that they take care of the production methods and working conditions pertaining to the goods they offer.
\end{abstract}

Keywords: Global Supply Chains; Ethics; Fairness; Global Markets

\section{Introduction}

Despite all technological advances, global supply chains are always based on the interaction of people. And wherever people interact, a kaleidoscope of ethical issues emerges.

Starting at the origins of the supply chain, the plight of individual farmers, minors or production workers is frequently examined in terms of working conditions or fair wages (Cotton et al., 2005; Locke and Romis, 2007). Other concerns pertain to the production itself. Issues like ecological soundness and infringement of intellectual property rights are frequently debated. Recently, the ethics of shifting production from one country to another has also been questioned. Moving further down the supply chain, middlemen like export- and import companies or wholesalers are commonly scrutinized for what should be their "fair share" in the value creation process. Critical debate has also focused on their discriminatory sales and purchase practices. Retailers, in turn, have been in the centre of the ethical debate for issues like truthful packaging or inept use of cause-

\footnotetext{
* Full Professor of International Marketing and Management, Vienna University of Economics and Business Administration (bodo.schlegelmilch@wu.ac.at)

** Research Assistant, Vienna University of Economics and Business Administration (magdalena.oeberseder@wu.ac.at)
} 
related marketing (Varadarajan and Menon, 1988). Finally, it appears that consumers are no angels either: for do they not quickly abandon any ethically motivated hesitations and willingly buy counterfeits whenever the price is low enough (Stöttinger et al., 2003; Penz et al., 2008)?

However, there is not only gloom and doom when it comes to ethics in international supply chains. Media attention focusing on the plight of Third World production workers is beginning to show results. Of course, many problems remain, but unsafe and unhealthy working conditions and ecological excesses are more difficult to hide. The Fair Trade movement, trying to ensure that Third World farmers are getting a better deal and curtailing the power of middlemen, has also gained momentum. Similarly, many retailers are now embracing ethical issues by emphasising, for example, that they take care of the production methods and working conditions pertaining to the goods they offer. In a similar vain, cause related marketing is used by some retailers to position themselves as particularly socially responsible. Finally, among consumers, "ethical shopping" is in vogue. Making an ethical stance with your supermarket trolley appears to be the order of the day.

In this paper, we take a closer look at some important ethical issues associated with international supply chains. Below, we start with a brief observation on the notion of fairness. Next, we focus on some central ethical issues relating to production. Moving down the supply chain, we then focus on the role of middlemen, both at the level of traders and wholesalers as well as on retailers. The following section centres on consumers who, on the one hand, are the driving force behind many positive ethical developments but, on the other hand, are also part of the problem due to their demands and own unethical behaviour. In closing, we question whether the extant research endeavours focus too much on micro-issues and neglect the bigger picture. Moreover, we offer some suggestions for future research on ethics in global supply chains.

\section{Differing Perceptions of Fairness}

Tensions in international supply chains frequently arise because something is perceived to be unfair by the actors involved. Indeed, to agree on what is fair appears to be extremely difficult. Bolton et al. (2003) have defined "fairness" as "a judgement of whether an outcome and / or the process to reach an outcome are reasonable, acceptable or just." And while there are many definitions of fairness, the root cause of many disagreements lies in the operationalisation of fairness.

In philosophy, a number of scholars discussed morality and fairness. Going back to ancient Greek, the philosopher Plato, for instance, thought of morality as requiring conformity to eternal forms of the good and the true. Centuries later, Emanuel Kant took up this subject again and formulated the categorical imperative: "Act only according to that maxim whereby you can at the same time will that it should become a universal law." (Schülein and Reitze, 2005).

And of course, morality is the core issue in all religions, too. 
$\square$ In the gospel according to Matthew, for example, morality and indirectly fairness are addressed: "Do unto others as you would have them do unto you." (Matthew 7:12) or in the Islam: "Select for your brother whatever you like for yourself" (Saying of the Holy Prophet Muhammad (P.B.U.H.)).

In the business ethics literature, a number of scholars also discussed the fairness construct and some identified and developed subcategories, such as price fairness (Kahneman et al., 1986a; Kahneman et al., 1986b; Maxwell, 1995; Campbell, 1999; Bolton et al., 2003; Xia et al., 2004) or service fairness (Seiders and Berry, 1998; Carr, 2007). A general approach was presented by Ferrell et al. (2008), who argue that fairness is "the quality of being just, equitable and impartial". According to Ferrell et al. (2008) the construct fairness is made up of three elements: equality (i.e. how wealth is distributed), reciprocity (i.e. the equal interchange of small favours) and optimization (i.e. the compromise between equality and maximum productivity).

However, none of these constructs and their operationalisations provide a convincing and coherent approach to resolving disputes about fairness. It is, and will always be, a big issue.

\section{Ethical Issues Pertaining to Producers}

Ethical issues concerning producers, particularly in developing countries, are currently at the forefront of debate. Manufacturers are confronted with a plethora of ethical subjects such as child labour, fair working conditions, fair wages, the ecological sustainability of their production methods, intellectual property right violations and counterfeits, to name just a few. Arguably, child labour is the issue where most agreement exists. However, despite the unethical, unjustifiable and degrading nature of child labour, it is still a problem in many developing countries. The problem is exacerbated when sub-contractors are involved. Nike, for instance, has been criticized in the media countless times as a purveyor of child labour. Instead of controlling local contract factories and ensuring that they do not employ children, the corporation defended itself with the lame excuse that children can easily fake the evidence of age (Boggan, 2001). Responding to criticism of child labour, Third World countries frequently point out that developed nations should not forget their own past. During the Industrial Revolution, children working in the textiles industry and in mining were very common indeed (Cruickshank, 1981; Nardinelli, 1990).

Another ethical concern of both companies and employees are healthy and safe working conditions. Nowadays, most industrialized countries have introduced regulations on health, safety and environmental (HSE) conditions. Yet the main problem in Western countries is not a lack of regulations and laws, but a reluctance to implement these laws and regulations. This is where the issue becomes an ethical problem, namely when companies fail to enforce regulations, such as wearing a safety helmet or passively permit workers to ignore appropriate safety regulations (Crane and Matten, 2007). In developing countries, concern shifts to the length of the working day and the working week. Many workers employed in sweatshops are reported to work more than 12 hours a day, six days a week. They 
have to fulfil quotas and work over-time if they do not want to be fired (Adams, 2002). But not only long working hours are problematic.

$\square$ Women cutting flowers in Columbia, for instance, have been found to suffer from sexual harassment and health problems because of the toxic pesticides (Financial Times, 2008).

People in the Third World often have no better alternative. It seems ironic but a study on sweatshops and Third World living standards presents results indicating that workers are better off if they work in sweatshops, since they can improve their living standards with their salary. Apart from that, the alternatives to working in sweatshops are even worse. Admittedly, sweatshops have poor working conditions and abhorrently low wages compared to Western standards.

\section{$\square$ However, a worker at the Kathy Lee Fifford sweatshop in Honduras earns on average USD 13 per day, which is 44\% more than the average salary of a Honduran worker (Powell and Skarbek, 2004). This should not be an excuse for sweatshops and the exploitation of human beings, but it sheds light on the vicious circle people in the Third World face.}

The issue of "fair remuneration" is also debated in industrialized countries. Although most European countries have established a statutory minimum wage, fair management remunerations are a hot topic of discussion, as some top managers earn a multiple of what their employees earn. Companies find themselves in a difficult dilemma. On the one hand, traditional income schemes are criticised, on the other hand companies have to compete for talented, hard-working top managers (Crane and Matten, 2007).

One big ethical issue for producers in many developing countries is the recognition of intellectual property rights such as patents, trademarks and copyrights. Manufacturing and selling counterfeit goods is regarded as unethical, since a manufacturer tries to capitalize on the goodwill of another company that has spent large sums of money and time on branding its product and creating an added value for its consumers (Laczniak and Murphy, 1993). Counterfeit goods have become a severe concern to global industry, as they account for a substantial proportion of world trade.

$\square$ According to the International Anti-Counterfeiting Coalition (IACC), U.S. manufacturers, for instance, lose USD 200 billion per year due to fake products (Freedmann, 1999). China is the world's biggest manufacturer of counterfeit products and seems to be holding on to this position, since exports of counterfeits and pirated products seem to be rising (IACC, 2006).

Closely connected to deceptive counterfeits, such as the purchase of "genuine" spare parts that turn out to be all but genuine, is the issue of product safety. However, product safety is also a concern in its own right, since consumers expect safe products and might sue a company if they harm, injure or kill people (Schlegelmilch, 1998). But safety lapses do not only harm consumers and have consequences for the individual company responsible for the problem. Sometimes, 
it is the entire industry or country from where the unsafe products emanates, that is held responsible. The recent scandals surrounding the toys made in China illustrates this point (The Economist, 2008).

The ethics of shifting of production sites from one country to another has also been questioned.

$\square$ Nokia, the world's largest manufacturer of mobile phones, is currently preparing one of the biggest shifts of production from Western to Eastern Europe. 2,300 jobs are lost in the West due to the move of its production plant to Romania (Financial Times, 2008).

However, it appears to be debatable whether shifting production locations is, in fact, an ethical issue at all. We would argue that it is the treatment of the employees to be made redundant that has an ethical dimension but not the shift of the production facility per se.

In the context of ethical issues concerning producers, the Fair Trade movement is gaining in importance. The movement aims to fight poverty by supporting disadvantaged producers living in developing countries. In the last decades, Fair Trade sales have grown by more than $20 \%$ each year and Fair Trade products are moving into mainstream distribution channels, since more and more people want to support poor farmers and be sure that the products they are consuming are produced under fair conditions (Krier, 2005). On the other hand, Fair Trade's cooperation with large, well-know companies, like Nescafé, and the distribution of Fair Trade products in supermarkets, might tarnish Fair Trade's image among its core constituency (Low and Davenport, 2006). The two main criticisms are that Fair Trade works too much within the system (Jacquiau, 2006) and that Fair Trade stops short of actively advocating more important trade policy changes (Boris, 2005).

But there are not only differing opinions on the strategy of Fair Trade within the organisation. External critique is more severe: First, there are those who point out that Fair Trade does not address the basic problem, namely that too much of a commodity, e.g. coffee, is produced in the first place. Instead, Fair Trade interventions would encourage market inefficiencies and overproduction (Hardford, 2005). Second, critical voices argue that Fair Trade is a political movement to organize labour. For instance, coffee certification is only available to co-operatives of small producers. This assumes that co-operatives are an inherently superior means of organizing labour (Economist, 2006). Third, it is claimed that fairness, in particular fair wages, are not achieved through Fair Trade, as only 10\% of the premium paid by consumers for Fair Trade products trickles down to the producers (Hardford, 2005).

\section{Ethical Issues Pertaining to Middlemen}

Ethical issues concerning middlemen are up for discussion, too. Questions of fair purchasing agreements, fair sales prices, fair share on wealth creation and fair treatment / relationship to producers continue to be debated. 
Fair purchasing agreements such as exclusive dealing (i.e. a middleman is not allowed to sell a competitor's products), exclusive territories (i.e. a middleman has the exclusive right to sell a manufacturer's product in an exclusive territory), or tying arrangements (i.e. a middleman has to buy more products although he might be interested in only one product), are discussed both from an ethical and illegal perspective (Lacziniak and Murphy, 1993).

The entire issue of discriminatory pricing is also of particular relevance for middleman. Why should middlemen offer better prices to economically powerful key accounts than to regular customers? What constitutes a fair margin for the middleman? And what would be a fair share on wealth creation for middlemen? Fair treatment and relationship to producers and customers is another issue, as dominant middlemen might misuse their bargaining power by switching arbitrarily from one small producer to another or by threatening customers with no or rationed supplies.

\section{Ethical Issues Pertaining to Retailers}

Retailers are subject to an entire spectrum of ethical concerns, some of which are not too dissimilar from those found at producers or middlemen. The ethical dimensions of packaging, for example, are widely discussed in the literature (Smith and Quelch, 1993; Schlegelmilch, 1998; Lacziniak and Murphy, 1993). In this context, ecological concerns continue to receive a lot of attention, since packaging causes about $40 \%$ of the world's waste (Schlegelmilch, 1998). Another ethical problem is untruthful packaging, including issues such as tampering with packages or slack fill, which cheats on the customers as packages are only partially full (Smith and Quelch, 1993). Similarly, misleading or unclear labelling continues to be a concern. If consumers are not able to understand the information presented to them correctly, they may make poor choices that are beneficial to the retailer.

A somewhat different angle is represented by the attempts of some retailers to use ethics as a positioning instrument to gain a competitive advantage. Specifically, retailers may attempt to present themselves as more ethical, more ecologically minded or more charitable than their competitors (Schlegelmilch, 1994). This could, for example, be achieved through so called cause-related marketing. Here, the retailer may suggest to their consumers that a certain percentage of the purchase price will be donated to a good cause, such as a children's charity. Of course, such cause-related marketing appeals are also used by manufacturers (e.g. each time you buy this product we pay a certain amount to X) or service companies (American Express run a campaign called charge against hunger).

$\square$ Currently, both Tesco Plc. and Co-operative Food Ltd. in the UK emphasise their association with Fair Trade to enhance their image. Tesco emphasises on its home page that it is proud of supporting Fair Trade, since their customers buy 1 in 3 Fair Trade products sold in Great Britain. ${ }^{1}$ Co-op stresses the importance of social responsibility and the necessity of supporting producers in developing countries, hence their support of Fair Trade products ${ }^{2}$. 
Although attempts to use ethics as a positioning instrument might improve a retailer's image and contribute to its competitive advantage, ethical positioning can also be dangerous and risky. Any type of ethical misconduct or problem will be viewed much more critically when the affected company attempted to position itself as particularly ethical.

$\square$ Sainsbury, for instance, sold a "truly eco-friendly" shopping bag that was Fair Trade certified. However, later it turned out that these bags were actually made by cheap labour in China and were not as environmentally friendly as the consumers were led to believe. Naturally, this resulted in a barrage of cynical critique in the UK tabloids (e.g. Daily Mail, 28 April, 2007).

\section{Ethical Issues Pertaining to Consumers}

Consumers throughout Europe increasingly want to be informed about the ecological and social context of the products they buy and use their shopping trolley to express social and ethical concern (e.g. De Pelmacker et al., 2005; Datamonitor, 2005).

Research conducted in the UK exemplifies this: According to a study ${ }^{3}$ conducted by Ipsos MORI, the U.K.'s second largest research company ${ }^{4}$, corporate social responsibility and ethics are increasingly important to British consumers. Fifty percent of the British public judge companies based on their social responsibility and their commitment towards ethical issues. Furthermore, consumers are caring more about ethical issues when buying products. Three in five Britons say that they prefer to buy recycled, GM (genetically modified) free, Fair Trade or eco-friendly products, although they do not regard themselves as ethical consumers, i.e. choosing products due to personal moral beliefs and values. However, $44 \%$ of the British consumers specifically avoid products because of ethical reasons (Worcester, 2000).

Coop's Ethics Study presents similar results. Consumers are now more concerned about ethical issues such as human rights, animal welfare, food integrity and the environment, than they were ten years ago. Apart from that, consumers are willing to pay more for ethical products than they did ten years ago. Eight in ten consumers (84\%) are now prepared to do so, compared with six in ten $(62 \%)$ in $1994 .^{5}$

Notwithstanding these encouraging developments, it has to be recognised that consumers are no angels. Consumer theft and fraud cost businesses worldwide billions of dollars. Other consumer misbehaviour also inflicts financial costs. Examples are unjustified complaints, psychological and physical abuse of employees or the many subtle forms of cheating, e.g., receiving too much change and not saying anything. And are consumers not too easily swayed to jettison their attitudes towards ethical issues when they buy non-deceptive counterfeits (Schlegelmilch and Stöttinger, 1999)? With few exceptions (Schlegelmilch et al., 2004), these more subtle forms of consumer misdemeanours have largely been overlooked in previous research. 


\section{Conclusions and Future Research Directions}

In this paper, we provide an overview and brief discussions on some of the most prominent ethical issues existing at various levels of the global supply chain (Table 1). But although the list of identified problems is already long, it is by no means exhaustive. Moreover, some issues, such as fair prices, concern virtually all stages of the supply chain, and associating them with a particular part of the framework is inevitably debatable.

Table 1: Key Ethical Issues in Global Supply Chains

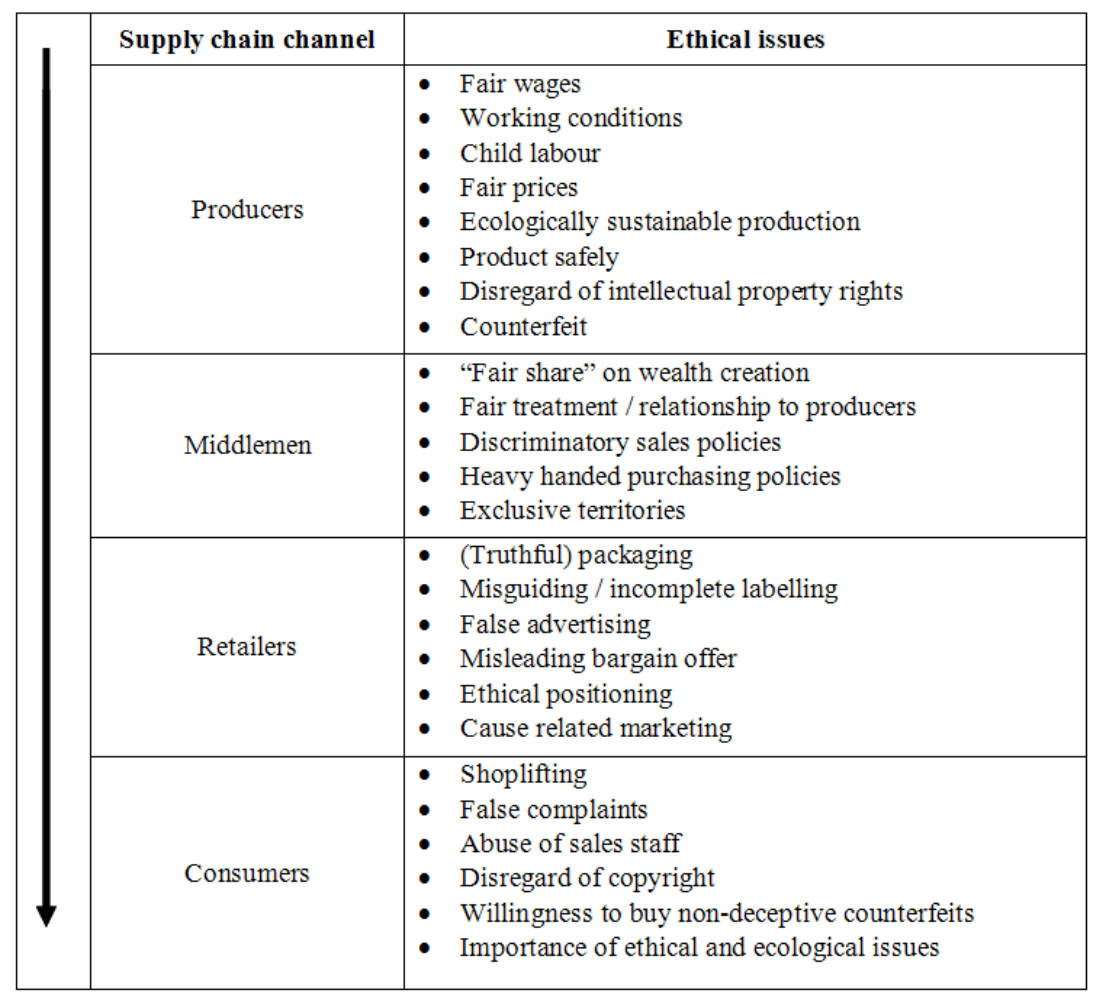

Another limitation of the paper is inherent in its perspective, i.e. we have only addressed the ethical tensions in international supply chains on a micro-level. Arguably, macro-level problems are even more severe and have a much greater potential to change the destiny of the citizens in Third World countries. Take the issues of tariffs and protectionism: The World Trade Organisation (WTO) now has over 150 members representing over $90 \%$ of world trade. Since 1950, many tariffs have fallen greatly, as for example the average tariffs for manufactured goods that decreased from $40 \%$ to below $4 \%$. However, EU tariffs for agricultural products and textiles, which are mainly produced in and exported from poor countries, remain at the $20 \%$ and $10 \%$ level, respectively (Economist, 2003). Is this fair?

Taking account of Skae and Barclay's (2007) suggestion that one way to reduce poverty is to increase a country's real export growth rate by more than 5 percent per annum, the prevailing tariff system does not appear to be just. Moreover, it has long been criticised that the European Union (EU) subsidises its agriculture and simultaneously harms producers in developing countries. The practice of dumping 
surplus agricultural products is destroying domestic markets in poor countries. It is estimated that the European sugar subsidies, for example, have caused a decrease of the world market price by $17 \%$. As a consequence, export chances of developing countries, such as India or Jamaica, are reduced (Godfrey, 2002). A debate on any of the ethical issues listed in Table 1 should not take place without being aware of such wider issues.

Despite this sobering note, the paper provides a number of useful pointers for future research endeavours. First, researchers could pick any one particular item, such as working conditions, and research the issue from the perspective of multiple stakeholders. Particularly interesting, in this context, would be the collection and analyses of representative empirical data to enable a more informed debate and move away from the anecdotal and case study based evidence that appears to dominate the literature. Second, there appears to be room for cross-cultural studies on the perception of ethical issues in the international supply chain. Adverting standards illustrate this point. What is regarded as unethical in one society, such as the use nudity in advertising, is regarded as acceptable in another. Is there room for a middle ground or can such differences in perception be overcome? Third, there is a need for extracting more concrete recommendations from conceptual ethical debates. Whether we ever reach agreement on what constitutes fairness remains doubtful considering the multiple stakeholders and interests involved in issues like shifting production abroad. However, if we were able to edge towards agreements on fair processes and evaluative frameworks, we would already have achieved a lot. Fourth, there appears to be a need to have a closer look at consumers as actors shaping ethics in global supply chains. While consumer demands and concerns have undoubtedly led to an increased awareness of ethical misconduct in the supply chain, contravening forces, such as the relentless pressures for low cost products and the apparent ease by which consumers are willing to ignore ethics when purchasing non-deceptive counterfeits or ignore copyright when downloading films or music from the Internet, should also not be ignored in research.

However, arguably the most urgent need for new research does not relate to any of the micro-level ethical issues discussed above, but to a more informed debate on the welfare implications of macro-economic measures. Particularly the international welfare implications of tariffs, taxes and trade rules appear to deserve more attention. In short, what appears to be needed in research that pertains to global supply chains is a shift from micro-topics to meso- and marco-ethical perspectives.

Taken collectively, we trust this paper made a contribution to raising awareness of the multitude of ethical problems in global supply chains. Quite clearly, a lot remains to be done and there is an urgent need for more research. However, all of us are actors in the economic system and are touched by these issues. Thus, we simply have to do more than just hope that the complex ethical issues will go away on their own. 


\section{Bibliography}

Adams R. J., Retail Profitability and Sweatshops: a Global Dilemma, Journal of Retailing and Consumer Service, Vol. 9, 2002, pp. 147-153.

http://dx.doi.org/10.1016/S0969-6989(01)00014-5

Boggan S., Nike Admits to Mistakes Over Child Labor, Indepdent UK online, 2001. (http://www.commondreams.org/headlines01/1020-01.htm)

Bolton L. E., Warlop L., Alba J. W., Consumer Perceptions of Price (un)fairness, Journal of Consumer Research, vol. 29, n. 3, 2003, pp. 474-491.

http://dx.doi.org/10.1086/346244

Boris J. P., Commerce Inéquitable, Hachette Littératures, Paris, 2005.

Campbell M., Why Did You Do That? The Important Role of Inferred Motive in Perceptions of Price Fairness, Journal of Product and Brand Management, vol. 8, n. 2, 1999, pp. 145-152. http://dx.doi.org/10.1108/10610429910266995

Carr C. L., The FAIRSERV Model: Consumer Reactions to Services Based on a Multidimensional Evaluation of Service Fairness, Decision Sciences, vol. 38, n. 1, 2007, pp. 107-130.

http://dx.doi.org/10.1111/j.1540-5915.2007.00150.x

Cotton A. P., Sohail M., Scott R. E., Towards Improved Labour Standards for Construction of Minor Works in Low Income Countries, Engineering, Construction and Architectural Management, vol. 12, n. 6, 2005, pp. 617-632.

http://dx.doi.org/10.1108/09699980510634164

Crane A., Matten, D., Business Ethics $2^{\text {nd }}$ Edition, Oxford University Press, New York, 2007.

Cruickshank M., Children and Industry, Manchester University Press, Manchester, 1981.

Daily Mail, The 'Unethical' Bag, April 28, 2007.

Datamonitor, Natural and Ethical Consumers, February 21, 2005.

De Pelsmacker P., Driesen L., Rayp G., Do Consumers Care about Ethics? Willingess to Pay for Fair-Trade Coffee, Journal of Consumer Affairs, vol. 39, n. 2, 2005, pp. 363-385.

http://dx.doi.org/10.1111/j.1745-6606.2005.00019.x

Ferrell O. C., Fraedrich J., Ferrell L., Business Ethics - Ethical Decision Making and Cases. $7^{\text {th }}$ Edition, Houghton Mifflin, Bosten and New York, 2008.

Financial Times Online, Nokia to Shift 2,300 German Jobs to Romania, January 16, 2008. (http://www.ft.com/cms/s/0/245b1c34-c357-11dc-b083-0000779fd2ac.html)

Financial Times, Valentine's Day Gifts Leave a Bitter Taste, February 14, 2008.

Freedman D. H., Fakers' Paradise, Forbes, vol. 163, n. 7, 1999, pp. 48-50.

Godfrey C., Stop the Dumping: How EU Agricultural Subsidies are Damaging Livelihoods in the Developing World, Oxfam Briefing Paper 31, 2002.

Harford, T., The Undercover Economist, Economic Affairs, Vol. 26, n. 4, 2005, pp. 92-93.

IACC, Submission of the International Anti-Counterfeiting Coalition, Inc. to the United States Trade Representative Special 301 Recommendations, 2006.

(http://www.iacc.org/resources/2006_USTR_Special_301.pdf)

Jacquiau C., Les Coulisses du Commerce Équitable, Éditions Mille et Une Nuits, Paris, 2006.

Kahneman D., Knetsch J .L., Thaler R. H., Fairness and the Assumptions of Economics, Journal of Business, Vol. 59, n. 4, 1986, pp. 285-300.

http://dx.doi.org/10.1086/296367

Kahneman D., Knetsch J. L., Thaler R. H., Fairness as a Constraint on Profit Seeking: Entitlements in the Market, American Economic Review, vol. 76, n. 4, 1986, pp. 728-741.

Krier J. M., Fair Trade in 25 European Countries: Facts and Figures on Fair Trade in 25 European Countries, 2005. (http://www.fairtrade-advocacy.org/ftineurope2005.html)

Laczniak G. R., Murphy P. E., Ethical Marketing Decisions, Allyn \& Bacon, U.S, 1993.

Locke R., Romis M., Improving Work Conditions in Global Supply Chains, MIT Sloan Management Review, vol. 48, n. 2, 2007, pp. 53-62. 
Low W., Davenport E., Mainstreaming Fair Trade: Adoption, Assimilation, Appropriation, Journal of Strategic Marketing, vol. 14, n. 4, 2006, pp. 315-327.

http://dx.doi.org/10.1080/09652540600947912

Maxwell S., What Makes a Price Increase Seem Fair?, Pricing Strategy \& Practice, vol. 3, n. 4, 1995, pp. 21-28.

Nardinelli C., Child Labor and the Industrial Revolution, Indiana University Press, Bloomington, 1990.

Penz E., Schlegelmilch B. B., Stöttinger B., Voluntary Purchase of Counterfeit Products: Empirical Evidence from four Countries, Journal of International Consumer Marketing, forthcoming, 2008. http://dx.doi.org/10.1080/08961530802125456

Powell B., Skarbek D., Sweatshops and Third World Living Standards: Are the Jobs Worth the Sweat?, Independent Institute Working Paper 53, 2004.

Schlegelmilch B. B., Green, Ethical and Charitable: another Marketing Ploy or a New Marketing Era, M. J. Baker (ed.), Perspectives on Marketing Management, vol. 4, 1994, pp. 55-71.

Schlegelmilch B., Marketing Ethics - An International Perspective, Thompson Learning, U.K, 1998.

Schlegelmilch B. B., Stöttinger B., Der Kauf gefälschter Markenprodukte: Die Lust auf das Verbotene, Marketing Zeitschrift für Forschung und Praxis, vol. 3, 3. Quartal,, 1999, pp. 196-208.

Schlegelmilch B. B., Cornwell B.T., Babakus E., Mitchell V. W., Reactions to Unethical Consumer Behavior Across Six Countries, Journal of Consumer Marketing, vol. 21, n. 4, 2004, pp. 254-263. http://dx.doi.org/10.1108/07363760410842165

Schülein J. A., Reitze S., Wissenschaftstheorie für Einsteiger $2^{\text {nd }}$ Edition, Facultas, Vienna, 2005.

Seiders K., Berry L.L., Service Fairness: What It Is and Why It Matters, Academy of Management Executive, vol. 12, n. 2, 1998, pp. 8-20. http://dx.doi.org/10.5465/AME.1998.650513

Skae O., Barclay B., Managing the Linkage between Export Development and Poverty Reduction: an Effective Framework, Management Decision, Vol. 45, n. 8, 2007, pp. 1208-1223. http://dx.doi.org/10.1108/00251740710819005

Smith N. C., Quelch J.A., Ethics in Marketing, Irwin, U.S, 1993.

Stöttinger B., Penz E., Schlegelmilch B. B., Why 'The Real Thing' is sometimes Less Attractive: Insights into Purchasing Behavior for Counterfeit Goods, Annual Meeting of the Academy of International Business, Monterey, California, July 5-8, 2003.

The Economist, The Cancun Challenge, September 6, 2003.

The Economist, Voting with your Trolley, December 9, 2006.

The Economist, Chinese Toys: No Fun and Games, January 10, 2008.

Varadarajan R., Menon A., Cause-Related Marketing: A Coalignment of Marketing Strategy and Corporate Philanthorpy, Journal of Marketing, Vol. 52, n. 3, 1988, pp. 58-74. http://dx.doi.org/10.2307/1251450

Worcester R., Ethical Consumerism Research, 2000. (http://www.ipsos-mori.com/polls/2000/coopcsr.shtml)

Xia L., Monroe K., Cox J. L., The Price is Unfair! A Conceptual Framework of Price Fairness Perceptions!, Journal of Marketing, Vol. 68, n. 10, 2004, pp. 1-15.

http://dx.doi.org/10.1509/jmkg.68.4.1.42733

\section{Notes}

${ }^{1}$ http://www.tescocorporate.com/economy

${ }^{2}$ http://www.co-operative.co.uk/en/food/fairtrade/

${ }^{3}$ MORI conducted 1,970 interviews among a representative sample of the British public (adults aged 15 and over), across 151 sampling points. All interviews were conducted face-to-face in respondents' homes between 18 and 22 May 2000. 
${ }^{4}$ http://www.ipsos-mori.com/about/index.shtml

5 Between December 1994 and March 1995, the Co-op surveyed 31,000 people* for its Responsible Retailing Report and, in early 2004, the Coop published the results of a new ethical study with a sample of 29,500 people**. [* (surveyed by Gallup - 30,000 consumers and members and 1,000 general public) $* *$ (surveyed by NOP $-28,500$ consumers and members and 1,000 general public)]. 